\title{
Influence of Remelting Treatment on Corrosion Behavior of Amorphous Alloys
}

\author{
Liu Jingtao ${ }^{1,2}$, Hou Jixin ${ }^{3}$, Zhang Xiaorong ${ }^{1,2}, \quad$ Guo Jing ${ }^{1,2}, \quad$ Xu Lingfeng ${ }^{1,2}, \quad$ Fan \\ Guiju ${ }^{1,2}$
}

${ }^{1}$ Shandong Agricultural University, Taian 271018, China; ${ }^{2}$ Shandong Provincial Key Laboratory of Horticultural Machineries and Equipments, Taian 271018, China; ${ }^{3}$ Soochow University, Suzhou 215021, China

\begin{abstract}
The corrosion behavior of $\mathrm{Gd}_{56} \mathrm{Al}_{26} \mathrm{Co}_{18}$ and $\mathrm{Sm}_{56} \mathrm{Al}_{26} \mathrm{Co}_{18}$ amorphous alloys in $0.01 \mathrm{~mol} / \mathrm{L} \mathrm{NaOH}$ solution has been researched by polarization curves, EIS technique, XRD and SEM. The free volume was also investigated by DSC technique. We find that the corrosion resistance of amorphous alloys in $0.01 \mathrm{~mol} / \mathrm{L} \mathrm{NaOH}$ solution increases after remelting. The corrosion resistance of Gd-based amorphous ribbons is better than that of the Sm-based amorphous ribbons in $0.01 \mathrm{~mol} / \mathrm{L} \mathrm{NaOH}$ solution. In addition, the amount of free volume of remelting amorphous ribbons is less than that of first-time melting amorphous ribbons.
\end{abstract}

Key words: corrosion behavior; amorphous alloys; electrochemical impedance spectroscopy (EIS); free volume

Over the past decade, amorphous alloys have been extensively investigated because of their superior properties, such as high strength ${ }^{[1]}$, and excellent corrosion resistance ${ }^{[2]}$. Liu et al. found that compression has an important effect on the corrosion resistance of $\mathrm{Al}_{86} \mathrm{Ni}_{9} \mathrm{La}_{5}$ amorphous alloy ${ }^{[3]}$. The thermally induced relaxation can also enhance the corrosion resistance of amorphous $\mathrm{Al}_{87} \mathrm{Co}_{7} \mathrm{Ce}_{6}$ alloy ${ }^{[4]}$. Ye et al. found that remelting treatment can improve the glass-forming ability of $\mathrm{Fe}_{78} \mathrm{Si}_{9} \mathrm{~B}_{13}$ amorphous alloy ${ }^{[5]}$. Our previous work also showed that remelting treatment could enhance the glass-forming ability and thermal stability of $\mathrm{Gd}_{56} \mathrm{Al}_{26} \mathrm{Co}_{18}$ and $\mathrm{Sm}_{56} \mathrm{Al}_{26} \mathrm{Co}_{18}$ bulk metallic glasses $(\mathrm{BMG})^{[6]}$. Therefore, it is valuable to study the influence of remelting treatment on corrosion resistance of amorphous ribbons.

In general, the amorphous ribbons are prepared by rapid cooling of metal liquids, so the liquids have significant effects on the formation and the properties of amorphous ribbons ${ }^{[7]}$. The heredity theory of liquids and solids has been widely investigated ${ }^{[8]}$. It is necessary to carry out extensive research on the effects of remelting treatment and structure heredity of amorphous ribbons.

A free volume model was proposed by Morrel H. Cohen and David Turnbull ${ }^{[9]}$, and then developed by Cohen and Spaepen ${ }^{[10,11]}$. Beukel et al. found that the change of enthalpy had a positive relation with the change of free volume $^{[12]}$ :

$$
\Delta H=\beta \Delta x
$$

where, $\Delta H$ is the change of enthalpy, $\beta$ is a constant and $\Delta x$ is the change of free volume per atomic volume. According to this equation, the method of differential scanning calorimetry had been widely used to study the free volume of amorphous alloys ${ }^{[13,14]}$.

In the present paper, the influence of remelting treatment on corrosion resistance of $\mathrm{Gd}_{56} \mathrm{Al}_{26} \mathrm{Co}_{18}$ and $\mathrm{Sm}_{56} \mathrm{Al}_{26} \mathrm{Co}_{18}$ amorphous alloys were investigated by polarization curves and electrochemical impedance spectroscopy (EIS). In addition, the free volume change was also analyzed by DSC.

\section{Experiment}

The $\mathrm{Gd}_{56} \mathrm{Al}_{26} \mathrm{Co}_{18}$ and $\mathrm{Sm}_{56} \mathrm{Al}_{26} \mathrm{Co}_{18}$ master alloys with

$\overline{\text { Received date: February 14 }}, 2016$

Foundation item: National Nature Science Foundation of China (51301098)

Corresponding author: Guo Jing, Associate Professor, College of Mechanical and Electronic Engineering, Shandong Agricultural University, Taian 271018, P. R. China, Tel: 0086-538-8246822, E-mail: gjcp1980@ hotmail.com 
nominal composition were made by alloying high-purity elements (99.9\% at least) in an arc furnace under argon atmosphere, which were remelted three times to guarantee the homogeneity. The first-time melting alloys $\mathrm{Gd}_{56} \mathrm{Al}_{26} \mathrm{Co}_{18}$ (1) and $\mathrm{Sm}_{56} \mathrm{Al}_{26} \mathrm{Co}_{18}$ (1) were prepared by single roller spinning apparatus. Then, the first-time melting alloys as master alloy were remelted to prepare the remelting alloys $\mathrm{Gd}_{56} \mathrm{Al}_{26} \mathrm{Co}_{18}$ (2) and $\mathrm{Sm}_{56} \mathrm{Al}_{26} \mathrm{Co}_{18}$ (2). The amorphous structure was studied by $\mathrm{X}$-ray diffractometry (XRD) with $\mathrm{CuK} \alpha$ radiation. The surface morphologies of the ribbons after electrochemical tests were examined using scanning electron microscope (SEM, Ultra-55). Differential scanning calorimetry (DSC) was detected at a constant heating rate of $10 \mathrm{~K} / \mathrm{min}$ under a flow of argon.

Prior to the electrochemical measurement, the exposed surface area of all as-quenched samples was polished with 1200\# emery paper. In addition, electrochemical measurement was carried out using a typical three-electrode system: work electrode, platinum counter electrode and reference electrode. The polarization curves in $0.01 \mathrm{~mol} / \mathrm{L}$ $\mathrm{NaOH}$ solution were obtained using LK2010 advanced electrochemical workstation with a scan rate of $5 \mathrm{mV} / \mathrm{s}$. Then, EIS was performed in the frequency range from $10^{6}$ to $0.1 \mathrm{~Hz}$, with a sinusoidal wave perturbation of $5 \mathrm{mV}$ in $0.01 \mathrm{~mol} / \mathrm{L} \mathrm{NaOH}$ solution.

\section{Results and Discussion}

Fig.1 shows the $\mathrm{X}$-ray diffraction patterns of the first-time melting $\mathrm{Gd}_{56} \mathrm{Al}_{26} \mathrm{Co}_{18}$ (1) and remelting $\mathrm{Gd}_{56} \mathrm{Al}_{26} \mathrm{Co}_{18}$ (2) amorphous ribbons, which displays only a diffraction peak of both alloys corresponding to a fully amorphous structure, denoting the homogeneous amorphous structures. The result accords with our previous works, which showed the first-time melting $\mathrm{Sm}_{56} \mathrm{Al}_{26} \mathrm{Co}_{18}$ (1) and remelting $\mathrm{Sm}_{56} \mathrm{Al}_{26} \mathrm{Co}_{18}(2)$ were all amorphous structure ${ }^{[15]}$.

The polarization curves of corrosion behavior of first-time melting and remelting amorphous alloys $\mathrm{Gd}_{56} \mathrm{Al}_{26} \mathrm{Co}_{18}$ and $\mathrm{Sm}_{56} \mathrm{Al}_{26} \mathrm{Co}_{18}$ in $0.01 \mathrm{~mol} / \mathrm{L} \mathrm{NaOH}$ solution are shown in Fig.2. In addition, the corresponding corrosion potential and corrosion current density are listed in Table 1. As shown in Table 1, the corrosion potential of remelting amorphous ribbons is higher than that of first-time amorphous ribbons for the two alloys, and the corrosion current density decreases after the remelting process. In other words, remelting treatment improves the corrosion resistance of $\mathrm{Gd}_{56} \mathrm{Al}_{26} \mathrm{Co}_{18}$ and $\mathrm{Sm}_{56} \mathrm{Al}_{26} \mathrm{Co}_{18}$ amorphous alloys. In addition, Qin et al found that the different corrosion behavior of bulk metallic glass (BMG) $\mathrm{Zr}_{55} \mathrm{Al}_{10} \mathrm{Cu}_{30} \mathrm{Ni}_{5-x} \mathrm{Pd}_{x}(x=0,5$, at\%) was attributed to glass forming ability (GFA) ${ }^{[16]}$.

What's more, it is obvious that corrosion current density of Gd-based amorphous ribbons is smaller than that of the Sm-based ones in $\mathrm{NaOH}$ solution. When the Gd-based

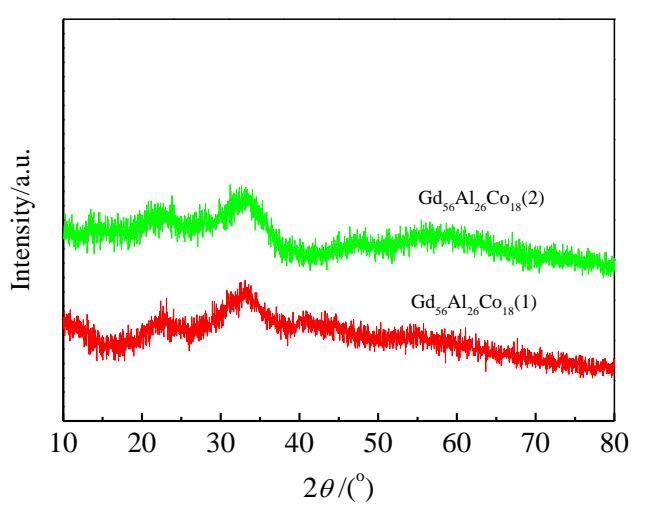

Fig.1 XRD patterns of the amorphous ribbons prepared by firsttime melting $\mathrm{Gd}_{56} \mathrm{Al}_{26} \mathrm{Co}_{18}(1)$ and remelting $\mathrm{Gd}_{56} \mathrm{Al}_{26} \mathrm{Co}_{18}(2)$

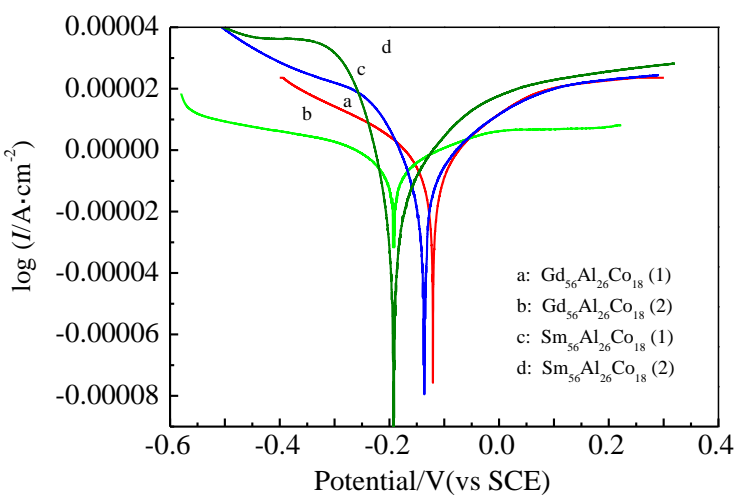

Fig.2 Polarization curves of Sm-based and Gd-based amorphous ribbons in $0.01 \mathrm{~mol} / \mathrm{L} \mathrm{NaOH}$ solution

Table 1 Corrosion potential $E_{\text {corr }}$ and corrosion current density $I_{\text {corr }}$ of Sm-based and Gd-based amorphous ribbons in $0.01 \mathrm{~mol} / \mathrm{L} \mathrm{NaOH}$ solution

\begin{tabular}{ccc}
\hline Amorphous ribbon & $E_{\text {corr }} / \mathrm{mV}$ & $I_{\text {corr }} / \times 10^{-4} \mathrm{~A} \cdot \mathrm{cm}^{-2}$ \\
\hline $\mathrm{Gd}_{56} \mathrm{Al}_{26} \mathrm{Co}_{18}(1)$ & -120.6 & 0.2029 \\
$\mathrm{Gd}_{56} \mathrm{Al}_{26} \mathrm{Co}_{18}(2)$ & -113.6 & 0.1173 \\
$\mathrm{Sm}_{56} \mathrm{Al}_{26} \mathrm{Co}_{18}(1)$ & -121.0 & 0.7436 \\
$\mathrm{Sm}_{56} \mathrm{Al}_{26} \mathrm{Co}_{18}(2)$ & -112.4 & 0.6531 \\
\hline
\end{tabular}

amorphous ribbons are put into the $\mathrm{NaOH}$ solution, $\mathrm{Gd} \rightarrow \mathrm{Gd}^{3+}+3 \mathrm{e}, \mathrm{Al} \rightarrow \mathrm{Al}^{3+}+3 \mathrm{e}, \mathrm{Co} \rightarrow \mathrm{Co}^{2+}+2 \mathrm{e}$ are considered as the anodic reactions, and for $\mathrm{Sm}$-based amorphous ribbons, $\mathrm{Sm} \rightarrow \mathrm{Sm}^{3+}+3 \mathrm{e}, \mathrm{Al} \rightarrow \mathrm{Al}^{3+}+3 \mathrm{e}, \mathrm{Co} \rightarrow \mathrm{Co}^{2+}+2 \mathrm{e}$ as the anodic reactions; the oxygen reduction and hydrogen evolution are the cathodic reactions for two kinds of amorphous ribbons ${ }^{[17,18]}$. Afterwards, hydrated oxides such as $\mathrm{Gd}(\mathrm{OH})_{3}, \mathrm{Co}(\mathrm{OH})_{2}, \mathrm{Sm}(\mathrm{OH})_{3}$, are precipitated to form a surface protection film ${ }^{[19]}$. In the two corrosion reactions, Gd and Sm are the only different elements for two nominal compositions. As we all know, the effectiveness of the Gd element on the corrosion is better than that of Sm element. 
In the present paper, the corrosion resistance of Gd-based amorphous ribbons is better than that of the Sm-based amorphous ribbons which can be ascribed to the difference of Gd and Sm element of oxide characters ${ }^{[17]}$.

The Nyquist diagrams for the samples at open potentials are shown in Fig. 3 in $0.01 \mathrm{~mol} / \mathrm{L} \mathrm{NaOH}$. Only one capacitive loop can be observed for the four samples, which indicates one time constant. The fitting impedance spectrum of amorphous ribbons can be obtained by equivalent circuit, as shown in Fig.4, and the physical quantities containing the solution resistance $\left(R_{\mathrm{s}}\right)$, the double layer capacitance CPE $\left(Q_{\mathrm{dl}}\right)$, and the charge transfer resistance $\left(R_{\mathrm{t}}\right)$ are listed in Table 2. As can be seen from Table 2, the charge transfer resistance of remelting amorphous ribbons increases after the remelting treatment. Meng et al. had found that the larger $R_{\mathrm{t}}$ corresponded to the higher corrosion resistance ${ }^{[20]}$. Therefore, these results are consistent with those of polarization curves in $0.01 \mathrm{~mol} / \mathrm{L} \mathrm{NaOH}$.
Fig.5 shows SEM micrographs of the first-time melting $\mathrm{Sm}_{56} \mathrm{Al}_{26} \mathrm{Co}_{18}$ (1), $\mathrm{Gd}_{56} \mathrm{Al}_{26} \mathrm{Co}_{18}$ (1) amorphous ribbons, and remelting $\mathrm{Sm}_{56} \mathrm{Al}_{26} \mathrm{Co}_{18}$ (2), $\mathrm{Gd}_{56} \mathrm{Al}_{26} \mathrm{Co}_{18}$ (2) amorphous ribbons before corrosion. Fig. 6 displays SEM micrographs of amorphous ribbons after corrosion in 0.01 $\mathrm{mol} / \mathrm{L} \mathrm{NaOH}$ solution. It can be seen that compared with the SEM micrographs after corrosion in $0.01 \mathrm{~mol} / \mathrm{L} \mathrm{NaOH}$ solution, the structures of the alloys before corrosion are very even without white particles on the surface. In addition, there are more white particles on the surface of remelting $\mathrm{Sm}_{56} \mathrm{Al}_{26} \mathrm{Co}_{18}(2)$ and $\mathrm{Gd}_{56} \mathrm{Al}_{26} \mathrm{Co}_{18}(2)$ amorphous alloys than on the surface of the first-time melting $\mathrm{Sm}_{56} \mathrm{Al}_{26} \mathrm{Co}_{18}(1)$ and $\mathrm{Gd}_{56} \mathrm{Al}_{26} \mathrm{Co}_{18}$ (1) amorphous alloys. Li et al. found that $\mathrm{Fe}$-based glassy ribbons with $0.2 \mathrm{~T}$ magnetic field had lower corrosion resistance than that with $0 \mathrm{~T}$, as well as less white particles than with $0 \mathrm{~T}^{[21]}$. In other words,
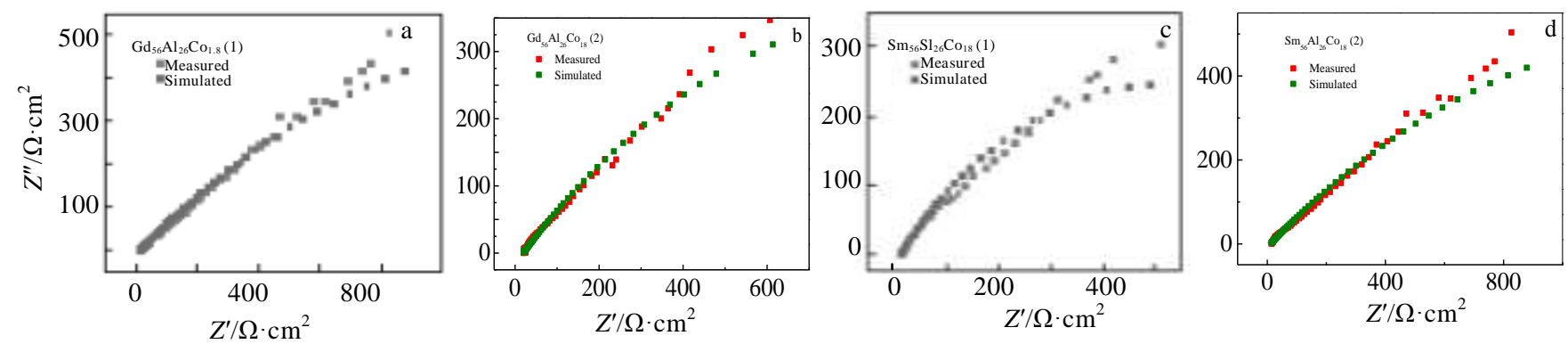

Fig.3 Experimental Nyquist plots of first-time melting and remelting amorphous alloys $\mathrm{Gd}_{56} \mathrm{Al}_{26} \mathrm{Co}_{18}$ and $\mathrm{Sm}_{56} \mathrm{Al}_{26} \mathrm{Co}_{18}$ in 0.01 mol/L $\mathrm{NaOH}$ solution: (a) $\mathrm{Gd}_{56} \mathrm{Al}_{26} \mathrm{Co}_{18}$ (1), (b) $\mathrm{Gd}_{56} \mathrm{Al}_{26} \mathrm{Co}_{18}$ (2), (c) $\mathrm{Sm}_{56} \mathrm{Al}_{26} \mathrm{Co}_{18}$ (1), and (d) $\mathrm{Sm}_{56} \mathrm{Al}_{26} \mathrm{Co}_{18}$ (2)

Table 2 Electrochemical parameters obtained from EIS

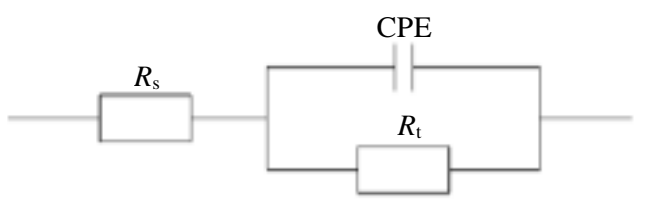
spectrum for first-time melting and remelting amorphous ribbons in $0.01 \mathrm{~mol} / \mathrm{L} \mathrm{NaOH}$ solution

\begin{tabular}{cccc}
\hline Amorphous ribbons & $R_{\mathrm{s} /} \Omega \cdot \mathrm{cm}^{-2}$ & $R_{\mathrm{t} /} \Omega \cdot \mathrm{cm}^{-2}$ & $\mathrm{CPE}(Q) / \mu \mathrm{F} \cdot \mathrm{cm}^{-2}$ \\
\hline $\mathrm{Gd}_{56} \mathrm{Al}_{26} \mathrm{Co}_{18}(1)$ & 8.537 & 1637 & 0.001544 \\
$\mathrm{Gd}_{56} \mathrm{Al}_{26} \mathrm{Co}_{18}(2)$ & 18.9 & 2030 & 0.01323 \\
$\mathrm{Sm}_{56} \mathrm{Al}_{26} \mathrm{Co}_{18}(1)$ & 12.14 & 1032 & 0.001427 \\
$\mathrm{Sm}_{56} \mathrm{Al}_{26} \mathrm{Co}_{18}(2)$ & 10.47 & 3093 & 0.009162 \\
\hline
\end{tabular}

Fig.4 Equivalent circuit corresponding to Fig.3

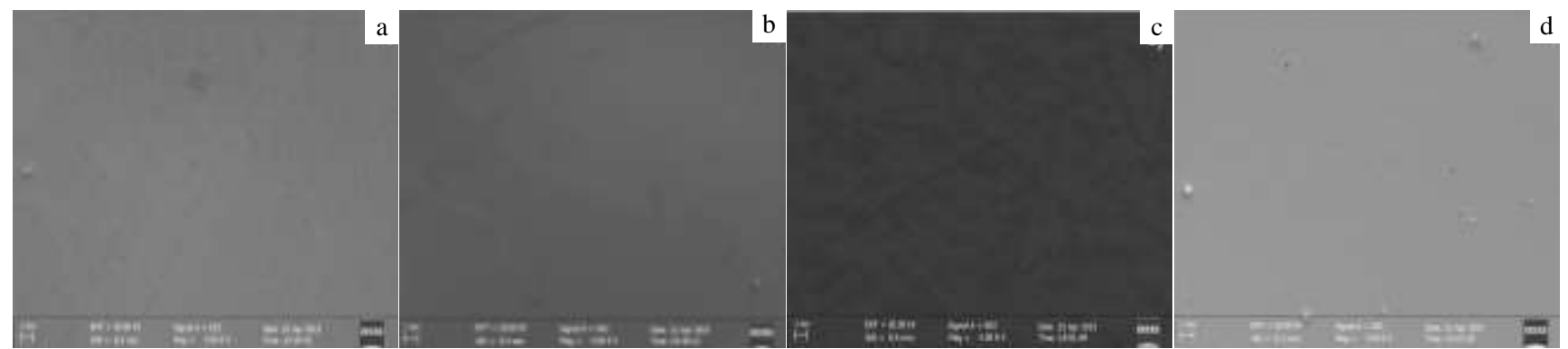

Fig.5 SEM images of amorphous ribbons prepared by first-time melting and remelting before corrosion: (a) $\mathrm{Sm}_{56} \mathrm{Al}_{26} \mathrm{Co}_{18}(1)$, (b) $\mathrm{Sm}_{56} \mathrm{Al}_{26} \mathrm{Co}_{18}$ (2), (c) $\mathrm{Gd}_{56} \mathrm{Al}_{26} \mathrm{Co}_{18}$ (1), and (d) $\mathrm{Gd}_{56} \mathrm{Al}_{26} \mathrm{Co}_{18}$ (2) 
the more the white particles, the higher the corrosion resistance. This is consistent with the conclusion that the remelting can enhance the corrosion resistance. In addition, the element contents by EDS analysis on the samples after electrochemical corrosion are shown in Table 3. It can be concluded that the main component of white particles are oxides. According to the viewpoint of structure heredity ${ }^{[22]}$, the amorphous ribbons prepared by remelting have more homogeneous liquid structure. In addition, our previous work has shown that the bulk metallic glass has more homogeneous amorphous structure after remelting treatment ${ }^{[7]}$. According to the mentioned above, $\mathrm{Sm}_{56} \mathrm{Al}_{26} \mathrm{Co}_{18}$ (2) and $\mathrm{Gd}_{56} \mathrm{Al}_{26} \mathrm{Co}_{18}$ (2) amorphous alloys have more homogeneous structure after remelting treatment. After remelting treatment, corrosion resistance of the amorphous ribbons prepared by remelting is promoted, and it may be attributed to the homogeneous structure of the amorphous ribbons prepared by first-time melting which is kept during the remelting procedure.

It is well known that the free volume has important influence on corrosion behavior of amorphous alloys. With the free volume increasing, the corrosion resistance decreased $^{[23,24]}$. In this paper, the amount of free volume was measured by DSC. Fig.7 shows the exothermal area of the four samples at the temperature below glass transition temperature $T_{\mathrm{g}}$, and the values of exothermal area are listed in Table 4. According to the change of enthalpy which has positive relation with the change of free volume, the amount of free volume of remelting amorphous ribbons should be less than that of first-time melting amorphous ribbons. In other words, remelting can reduce the free volume
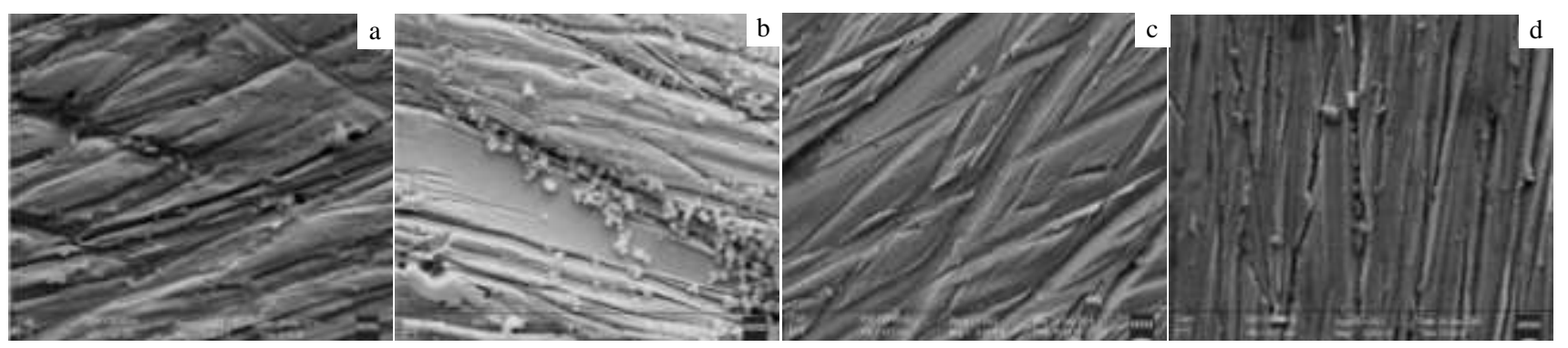

Fig.6 SEM morphologies of Sm-based and Gd-based amorphous ribbons: (a) $\mathrm{Sm}_{56} \mathrm{Al}_{26} \mathrm{Co}_{18}$ (1), (b) $\mathrm{Sm}_{56} \mathrm{Al}_{26} \mathrm{Co}_{18}(2),(\mathrm{c}) \mathrm{Gd}_{56} \mathrm{Al}_{26} \mathrm{Co}_{18}(1)$, and (d) $\mathrm{Gd}_{56} \mathrm{Al}_{26} \mathrm{Co}_{18}(2)$

of amorphous ribbons. As mentioned above, the corrosion resistance of remelting amorphous ribbons is enhanced, which is consistent with change of free volume. On the other hand, our previous work had shown that the property of bulk metallic glasses had tight relation with free volume and homogeneous microstructure after remelting treatment ${ }^{[6]}$. Therefore, the increase of corrosion resistance after remelting treatment can be ascribed to remelting amorphous ribbons containing the less excess free volume and the more homogeneous microstructure.
Table 3 Element concentration on surface-particlesofamorphous ribbons after electrochemical corroded analyzed by EDS (at\%)

\begin{tabular}{cccccc}
\hline Amorphous ribbons & $\mathrm{Gd}$ & $\mathrm{Sm}$ & $\mathrm{Al}$ & $\mathrm{Co}$ & $\mathrm{O}$ \\
\hline $\mathrm{Sm}_{56} \mathrm{Al}_{26} \mathrm{Co}_{18}(1)$ & 0 & 42.55 & 21.8 & 17.55 & 18.1 \\
$\mathrm{Sm}_{56} \mathrm{Al}_{26} \mathrm{Co}_{18}(2)$ & 0 & 43.36 & 22.98 & 17.66 & 16 \\
$\mathrm{Gd}_{56} \mathrm{Al}_{26} \mathrm{Co}_{18}(1)$ & 41.71 & 0 & 21.29 & 17.36 & 19.64 \\
$\mathrm{Gd}_{56} \mathrm{Al}_{26} \mathrm{Co}_{18}(2)$ & 41.05 & 0 & 22.45 & 16.32 & 20.18 \\
\hline
\end{tabular}

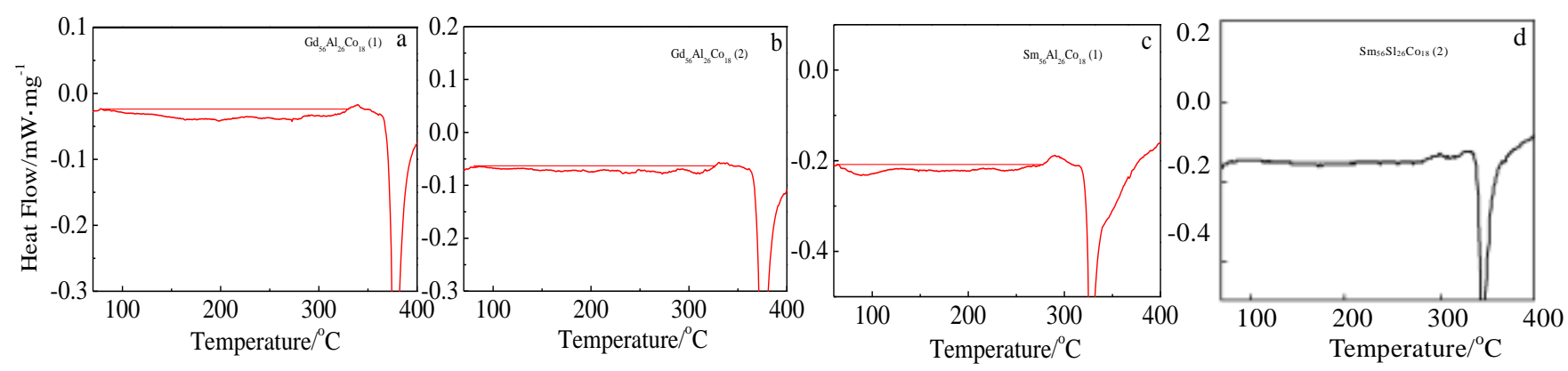

Fig.7 DSC curves of four samples with the heating rate of $10 \mathrm{~K} / \mathrm{min}$ : (a) $\mathrm{Gd}_{56} \mathrm{Al}_{26} \mathrm{Co}_{18}$ (1), (b) $\mathrm{Gd}_{56} \mathrm{Al}_{26} \mathrm{Co}_{18}$ (2), (c) $\mathrm{Sm}_{56} \mathrm{Al}_{26} \mathrm{Co}_{18}(1)$, and (d) $\mathrm{Sm}_{56} \mathrm{Al}_{26} \mathrm{Co}_{18}(2)$ 
Table 4 Exothermal area of four amorphous ribbons samples at the temperature below glass transition temperature $T_{\mathrm{s}}$

\begin{tabular}{cccc}
\hline $\mathrm{Sm}_{56} \mathrm{Al}_{26} \mathrm{Co}_{18}$ & $\mathrm{Sm}_{56} \mathrm{Al}_{26} \mathrm{Co}_{18}$ & $\mathrm{Gd}_{56} \mathrm{Al}_{26} \mathrm{Co}_{18}$ & $\mathrm{Gd}_{56} \mathrm{Al}_{26} \mathrm{Co}_{18}$ \\
$(1)$ & $(2)$ & $(1)$ & $(2)$ \\
\hline 2.65961 & 1.26644 & 2.81151 & 2.10434 \\
\hline
\end{tabular}

\section{Conclusions}

1) The corrosion resistance of amorphous alloys Sm56A126Co18 and Gd56A126Co18 in $0.01 \mathrm{~mol} / \mathrm{L} \mathrm{NaOH}$ solution increases after remelting.

2) The corrosion resistance of Gd-based amorphous ribbons is better than that of the Sm-based amorphous ribbons in $0.01 \mathrm{~mol} / \mathrm{L} \mathrm{NaOH}$ solution.

3) The charge transfer resistance of remelting amorphous ribbons increases after the remelting treatment.

\section{References}

1 Holt J B, Ankeny D C, Cline C F. Scripta Metallurgica[J], 1980, 14: 959

2 Pang S J, Zhang T, Asami K et al. Corrosion Science[J], 2002, 44: 1847

3 Liu Y, Wang W M, Zhang H D et al. J Mater Sci Technol[J], 2012, 28: 1102

4 Tailleart N R, Huang R, Aburada T et al. Corrosion Science [J], 2012, 59: 238

5 Ye S L, Li X Y, Bian X F et al. J Alloy Compd[J], 2013, 562: 143

6 Zhang Z L, Guo X H, Liu J T et al. J Alloy Compd[J], 2014, 588: 530
7 Li H, Wang G H, Bian X F. Journal of Chemical Physics $[\mathrm{J}]$, 2002, 116: 10809

8 Karakse E, Keskin M. Mater Design[J], 2011, 32: 4970

9 Cohen M H, Turnbull D. J Chem Phys[J], 1959, 31: 1164

10 Spaepen F. Acta Mater[J], 1977, 25: 407

11 Cohen M H, Grest G S. Phys Rev B[J], 1979, 20: 1077

12 Beukel A V D, Sietsma J. Acta Metall Mater[J], 1990, 38: 383

13 Slipenyuk A, Eckert J. Scripta Materialia[J], 2004, 50: 39

14 Launey M E, Kruzic J J, Li C et al. Applied Physics Letters[J], 2007, 91: 051913

15 Guo J, Liu J T, Yu H J et al. Corrosion Engineering Science and Technology[J], 2014, 49: 357

16 Qin F X, Zhang H F, Chen P et al. Mater Lett [J], 2004, 58: 1246

17 Meng Q G, Li J G, Bian X F. J Alloy Compd[J], 2006, 424: 350

18 Sunada S, Majima K, Akasofu Y et al. J Alloy Compd[J], 2006, 408-412: 1373

19 Mora N, Cano E, Polo J L et al. Corrosion Science[J], 2004, 46: 563

20 Meng Q G, Zhang S G, Li J G. J. Alloy Compd[J], 2008, 452: 273

21 Li Y J, An B, Wang Y G et al. Journal of Non-Crystalline Solids[J], 2014, 392-393: 51

22 Bian X F, Wang W M, Li H et al. Liquid Structure of Metals[M]. Shanghai: Shanghai Jiaotong University Press, 2003

23 Jiang W H, Jiang F, Green B A et al. Appl Phys Lett[J], 2007, 91: 041904

24 Jayaraj J, Gebert A, Schultz L. J Alloy Compd[J], 2009, 479: 257

\title{
重熔处理对铝基非晶合金腐蚀性能的影响
}

\author{
刘景涛 ${ }^{1,2}$, 侯纪新 ${ }^{3}$, 张晓蓉 ${ }^{1,2}$, 郭 晶 ${ }^{1,2}$, 许令峰 ${ }^{1,2}$, 禁桂菊 ${ }^{1,2}$ \\ (1. 山东农业大学, 山东 泰安 271018) \\ (2. 山东省园艺机械与装备重点实验室, 山东 泰安 271018) \\ (3.苏州大学, 江苏 苏州 215021)
}

\begin{abstract}
摘 要: 通过极化扫描, EIS, XRD 和 SEM 技术研究了 $\mathrm{Gd}_{56} \mathrm{Al}_{26} \mathrm{Co}_{18}$ 和 $\mathrm{Sm}_{56} \mathrm{Al}_{26} \mathrm{Co}_{18}$ 非晶合金在 $0.01 \mathrm{~mol} / \mathrm{L}$ 氢氧化钠溶液中的腐蚀行 为, 同时通过 DSC 研究了自由体积。非晶合金在 $0.01 \mathrm{~mol}$ 的 $\mathrm{NaOH}$ 碱溶液中腐蚀后发现经过重熔处理增加了它的耐腐蚀性能。 $\mathrm{Gd}$ 基 非晶条带在 $0.01 \mathrm{~mol} / \mathrm{L}$ 的 $\mathrm{NaOH}$ 碱溶液中的耐腐蚀性要优于 $\mathrm{Sm}$ 基非晶条带。另外通过研究发现，重熔后的非晶条带含有的自由体积 比第 1 次制备的非晶条带要少。
\end{abstract}

关键词：腐蚀行为; 非晶合金; 电化学阻抗图谱; 自由体积

作者简介: 刘景涛, 男, 1986 年生, 硕士, 山东农业大学机械与电子工程学院, 山东 泰安 271018, 电话: 0538-8246822, E-mail: liujingtao688@126.com 